\title{
The influence of settable parameters of switching gasoline/LPG on exhaust toxic emissions
}

The main objective of the studies shown in the paper was to develop a proper strategy for settable parameters of ECU to decrease total emission of toxic components in composition of exhaust during a cold start phase. The experimental research has been performed for engine running at idle and for engine running on the chassis dynamometer (performing European Driving Test NEDC).

Key words: alternative fuels, $L P G$, toxic emissions, ECU parameters, calibration

\section{Introduction}

Increasing air pollution in cities forces to consider every possible way of its reduction. Although the share of motor vehicles as a source of particulates PM2.5 to PM10 is small - less than $10 \%$ [5], actions taken by local governments for limiting vehicular traffic are much easier than remodelling home heating. Current engines, both self-ignition and modern spark ignition units, emit solid particles in the exhaust fumes during the heating phase. While it is true that methods of purifying exhaust gas from particulates has been very well developed especially those which are based on removing particulars of large size by exhaust gas filtration, but still smaller particles are passed through the filters. Alternatives to traditional diesel or gasoline fuel systems are fuel gases like methane gas or propane and butane mixture $[3,6]$. No solid particles are generated when these gases are burned. However, it should be notated that those gases are fossil fuels and their reserves are limited. With $100 \%$ usage of LPG will reduce the cycle by cycle variations within the cylinder and, improves the combustion characteristics and combustion stability [7].

In the presented paper, the authors focus on heating phase of a passenger car engine supplied by propane and butane (LPG) mixture. The aim of the experimental research was to determine the proper settable parameters of engine's control unit and their influence on toxic emission. However, fuel consumption and fuel costs were not a priority for the control strategy. The adhibition of particulate matter reducing fuels, according to the authors, is less expensive than replacing vehicles with new models with extensive but often failing exhaust systems.

\section{Approval requirements for dual fuel gasoline and LPG supply systems}

Emissions of toxic exhaust gas components are tested for LPG and CNG gas installations intended for vehicles of class $\mathrm{M} 1$ and $\mathrm{N} 1$ in accordance with regulation no. 83 of directive 70/220 / EEC [4]. For the Type I (NEDC) test on a chassis dynamometer, a reference car is designated. Other vehicles in which the installation will be implemented must have many features in common with the reference car. Measurements start with cold start at $20-30{ }^{\circ} \mathrm{C}$ ambient temperature. The engine of the vehicle adapted for LPG at the beginning of the test engine is fuelled with gasoline. It happens in some vehicles that time of engine running on petrol is extended to ease meeting emissions requirements . In order to counter this, Regulation 692/2008 requires that the running time of the petrol engine must not exceed 60 seconds. In this paper authors tried to examine fuel systems in winter conditions when that time is difficult to reach. Examinations are being conducted using two reference fuels of very different composition The properties of fuels are given in Table 1 [4]. The authors used regular petrol from petrol station.

\section{The settable parameters of supply controller deciding of fuel switching}

The change of combusted fuel occurs in modern systems automatically on the basis of the measured thermodynamic parameters in the gas fuel supply system and the parameters that influence on the flexibility of the fuel change. Parameters characterizing the state of the gas in the installation are:

- temperature of evaporator-reducer;

- temperature in the gas fuel rail;

- pressure in the gas fuel rail.

Additional switch decision variables are:

- delay in cutting off gasoline supply;

- the time elapsed since the start of the engine;

- current speed;

- recognition of whether the rotational speed is increasing or decreasing;

- delay in switching individual cylinders from petrol to gas.

The parameters listed above represent the majority of all parameters used in engine control unit. Although manufacturers only use some of them. Authors' studies are focused on evaporator reducer temperature because this parameter is the most commonly used and has the greatest influence on the correct change of fuel during heating.

\section{Phenomena affecting on proper fuel supply during heating phase of engine}

The most important process while cold starting of engine with spark ignition, is evaporating of the fuel and mixing it with air. This process is transient in relation to changeable air temperature and temperature of engine walls. In indirect injection engines when the engine is 
warmed up, the evaporation takes place largely on the hot surface of the intake valve head. In the cold engine this process is limited. Such evaporation is only possible for petrol supply because the optimum spray on the valve head is provided only for petrol injector. In the classic implementation of the supply system for the evaporated LPG , calibrated nozzles are screwed into the collector wall (Fig. 1).
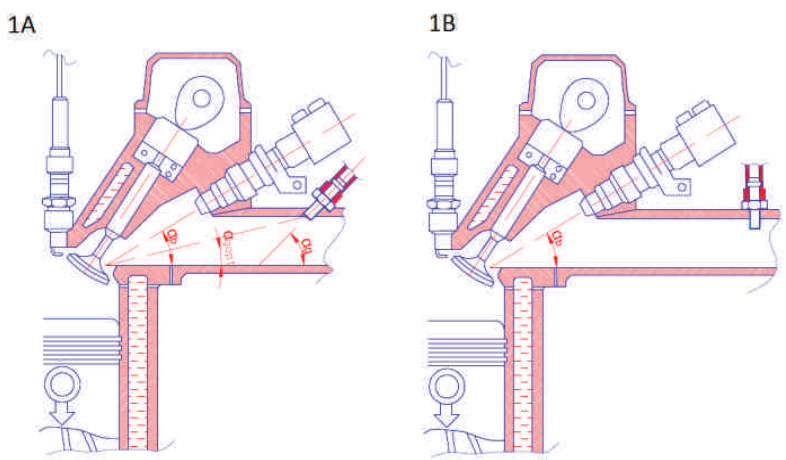

Fig.1. Placement of the gas inlet in the intake manifold: (1A) at an angle in the $\mathrm{Al}$ alloy manifold; (1B) perpendicular to the plastic collector

However, the best place for LPG nozzles is occupied by a gasoline injector. This creates the need to drive the gas from the solenoid valve to the nozzles trough the flexible conduit of thickness from ten to twenty inches. This solution is accompanied by unfavorable gas supply delays, bad angle of insertion of the stream into the collector, excessive distance from the nozzle to the inlet valve.

\section{Engine starting temperature}

The initial temperature of the engine coolant and the evaporator reducer, after a long standstill, are equal to the ambient temperature. At ambient temperature $+20^{\circ} \mathrm{C}$ heat state of fully-heated engine requires 8 hours to return to its original state. If the standstill takes less, the liquid temperature is higher than the ambient temperature. The temperature drop over time is very dependent on the environmental conditions. The decrease in coolant temperature been investigated for standstill in open air winter conditions. The measurements done by author showed a significant influence of atmospheric conditions on the dynamics of liquid cooling (Fig. 2). The strength and direction of the wind is very important. Lesser is the effect of air temperature. At low temperatures, the cooling liquid expedites the heat more quickly to the environment, especially just after engine shut off because of the temperature difference. Then the cooling curves are approaching each other. The temperature drop in moderate weather conditions $\left(-5\right.$ to $\left.+3^{\circ} \mathrm{C}\right)$ in windless weather is around $35^{\circ} \mathrm{C}$ in one hour. At the beginning of cooling about 30 minutes after stopping the temperature drops about $0.7^{\circ} \mathrm{C}$ min and in the next half hour $0.5^{\circ} \mathrm{C} / \mathrm{min}$. From Fig. 2 you can conclude that in winter conditions switching from petrol to gas will be almost instantaneous if the engine stop is less than an hour and a half. It would take about 6 hours to reach completely equal level out coolant temperature with ambient temperature in windless weather.

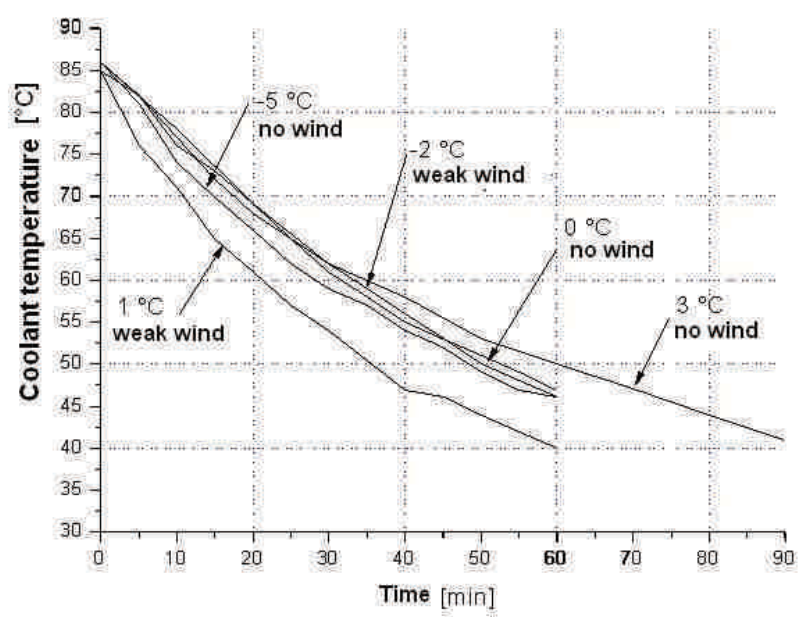

Fig. 2. Coolant temperature reduction after stopping Honda Accord 2.0 engine

\section{The examination of times of fuel switching}

During the winter, the engine starts at an unfavourably low temperature. To test the actual switching times from gasoline to evaporated gas, a test drive was performed with the registration of vehicle traffic parameters and operating parameters of fuel supply systems. The subject of research was Honda CRV 2.0 passenger car. For cold starts at $0^{\circ}$ and $5^{\circ}$, ride on the same routes were recorded. In order to switch fuels without increased emissions of toxic compounds, especially hydrocarbons, the control of the composition of the mixture in the feedback loop must begin beforehand. The detection of this control was based on the registration of short-term fuel correction (STFT) included in the gas supply system. Table 1 lists the times that have elapsed since the start of the engine to reach the test condition. Figure 2 shows an example of the registration of the parameters listed in Table 1.

Table 1. LPG reference fuels [4]

\begin{tabular}{|l|c|c|c|}
\hline Parameter & Unit & \multicolumn{2}{|c|}{ Fuel for light vehicles testing } \\
\cline { 3 - 4 } & & fuel A & fuel B \\
\hline Composition: & & & \\
content C3 & $\%$ & $30 \pm 2$ & $85 \pm 2$ \\
content C4 & $\%$ & rest & rest \\
content olefin & $\%$ & $\max .12$ & $\max .15$ \\
total sulphur content & $\mathrm{mg} / \mathrm{kg}$ & $\max .10$ & $\max .10$ \\
Number of motor octane & - & $\min .89$ & $\min .89$ \\
\hline
\end{tabular}

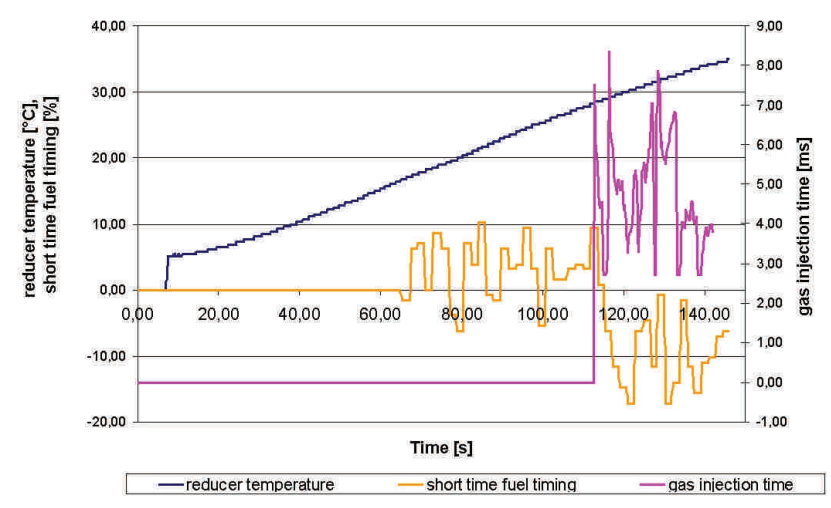

Fig. 3. Parameters related to fuel switching 


\section{Studies on emissions of toxic compounds during heating and fuels switching phase}

As the main objective of this work is to investigate the change in the composition of the exhaust gases during the warm-up phase of the engine, series of cold start tests were performed. The cumulative emission of different exhaust components was measured. The subject was a Nissan Micra 1.2 passenger car. In the first stage of research the exhaust gas composition was measured during cold start phase only for engine running at idle. The results are shown in Figures 4 and 5.

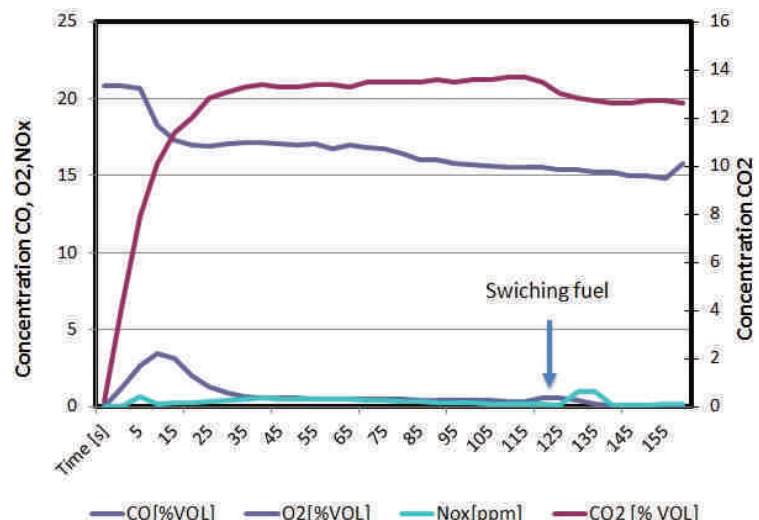

Fig. 4. Changes in the composition of toxic constituents and oxygen in the exhaust fumes during warm-up phase for engine at idle

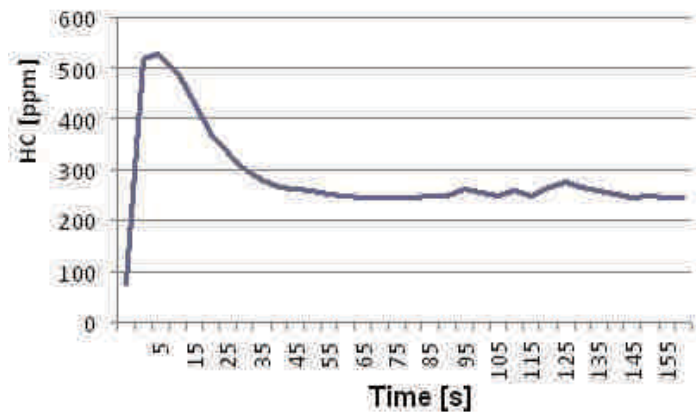

Fig. 5. Changes in the composition of hydrocarbons in the exhaust during warm-up phase for engine at idle

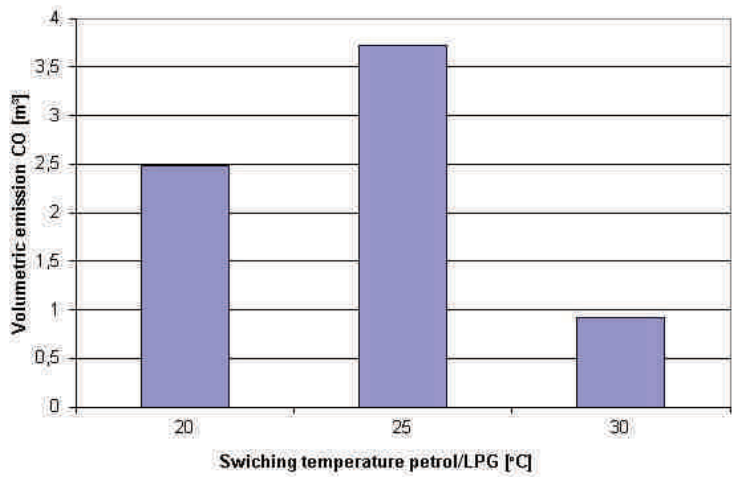

Fig. 6. Cumulative $\mathrm{CO}$ emissions in the fume gases from cold start to fuel switching moment

A typical phenomenon in the measurement is increased hydrocarbon emissions and reduced carbon monoxide emissions immediately just after fuel change. These elevated hydrocarbon emissions are the result of a lack of adequate mixing of the gas with low temperature air - are result of incomplete combustion.

The next stage of the study was the measurements on the chassis dynamometer during the implementation of the European type NEDC test. The composition of the exhaust gas was recorded during heating phase by setting the temperature of the evaporator reducer before each test as a decisive parameter for fuel's switch. Table 2 shows the switching times and total $\mathrm{CO}_{2}$ emissions from the beginning of the test to fuel's switch moment

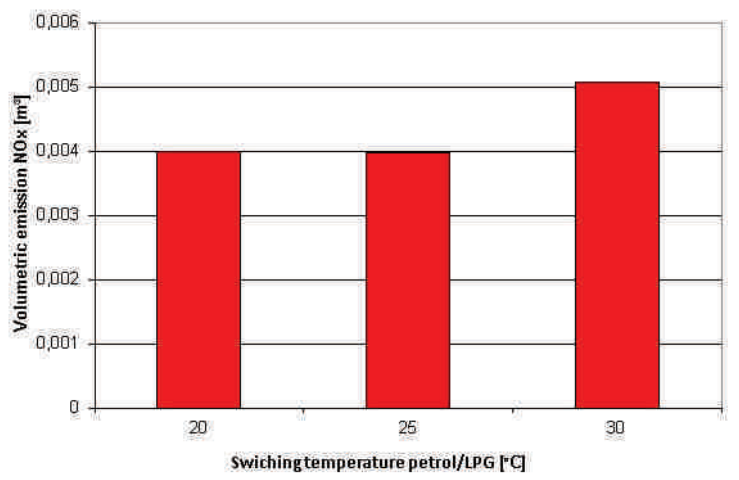

Fig. 7. Cumulative NOx emissions in the fume gases from cold start to fuel switching moment

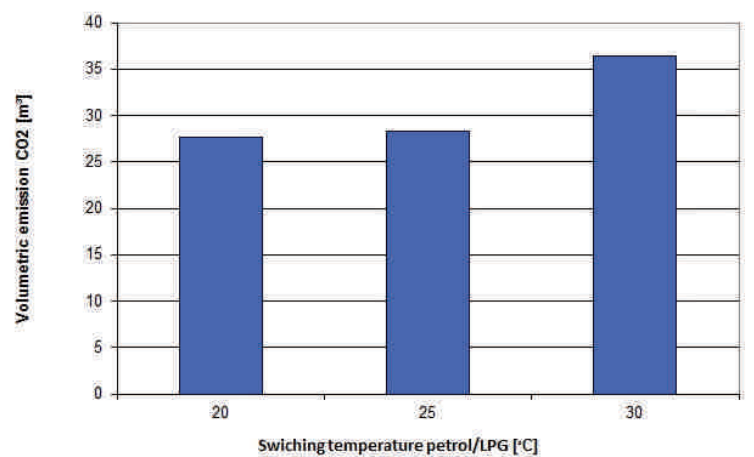

Fig. 8. Cumulative $\mathrm{CO}_{2}$ emissions in the fume gases from cold start to fuel switching moment

Table 2. Running times of processes that determine effective switching of fuels

\begin{tabular}{|l|c|c|}
\hline Starting temperature & $0^{\circ} \mathrm{C}$ & $5^{\circ} \mathrm{C}$ \\
\hline Start-up of closed-loop fuel-air mixture control (STFT) & $63 \mathrm{~s}$ & $51 \mathrm{~s}$ \\
\hline Reaching the temperature of evaporator reducer $25^{\circ} \mathrm{C}$ & $94 \mathrm{~s}$ & $75 \mathrm{~s}$ \\
\hline Switchover of fuels & $110 \mathrm{~s}$ & $84 \mathrm{~s}$ \\
\hline
\end{tabular}

Table 3. Parameters related to the process of warming up the LPG supply system for switching from petrol to LPG - NEDC test

\begin{tabular}{|l|c|c|c|}
\hline $\begin{array}{l}\text { Adjustable petrol/LPG switching } \\
\text { temperature }\end{array}$ & $20^{\circ} \mathrm{C}$ & $\begin{array}{c}25^{\circ} \mathrm{C} \\
(\text { stand. })\end{array}$ & $30^{\circ} \mathrm{C}$ \\
\hline Running time with gasoline & $109 \mathrm{~s}$ & $125 \mathrm{~s}$ & $164 \mathrm{~s}$ \\
\hline $\begin{array}{l}\text { Change of } \mathrm{CO} \text { emissions from } \\
\text { baseline at } 25^{\circ} \mathrm{C}\end{array}$ & $-33 \%$ & 0 & $-75 \%$ \\
\hline $\begin{array}{l}\text { Change of } \mathrm{HC} \text { emissions from } \\
\text { baseline at } 25^{\circ} \mathrm{C}\end{array}$ & - & 0 & $-47.4 \%$ \\
\hline $\begin{array}{l}\text { Change of } \mathrm{NO}_{\mathrm{x}} \text { emissions from } \\
\text { baseline at } 25^{\circ} \mathrm{C}\end{array}$ & $0 \%$ & 0 & $+27.4 \%$ \\
\hline $\begin{array}{l}\text { Change of } \mathrm{CO}_{2} \text { emissions from } \\
\text { baseline at } 25^{\circ} \mathrm{C}\end{array}$ & $-2.5 \%$ & 0 & $+29 \%$ \\
\hline
\end{tabular}




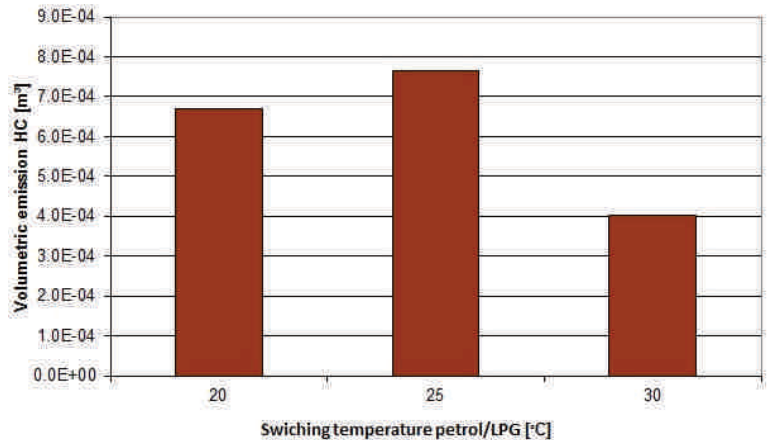

Fig. 9. Cumulative HC emissions in the fume gases from cold start to fuel switching moment

The test assumption was to set fuel switching temperatures that did not cause engine malfunction during the test run. The standard temperature has been set (temperature which is often chosen by installers) and two other one by five degrees higher and one five degrees lower than standard temperature. Based on the graphs, it can be stated that the reducer temperature settings for fuel switching in the range of $20-25^{\circ} \mathrm{C}$ do not significantly change the cumulative emissions of toxic compounds while engine working on petrol, except for carbon monoxide. Only increasing the switching temperature of reducer to $30^{\circ} \mathrm{C}$ results in a significant reduction in emissions especially of carbon monoxide and hydrocarbons.

\section{Conclusions}

Differentiated warm-up test of the propane and butane supply system were performed with a focus on the exhaust gas composition in this starting engine phase period. It has been found that the set-point (standard) switching temperature of reducer is not particularly beneficial due to the high emissions of carbon monoxide and hydrocarbons. Increasing the time of engine is running on gasoline result in reduction of toxic gas emissions and of course increasing the consumption of gasoline. Only nitric oxide emissions increase with engine's prolonged petrol working time. At low ambient temperatures cold start on petrol is significantly extending. For more general and up-to-date applications, similar measurements should be made using the WLTP test [2] for more cars at several starting temperatures.

\section{Bibliography}

[1] BIELACZYC, P., SZCZOTKA, A., PAJDOWSKI, P. WOODBURN, J. The potential of current European light duty LPG-fuelled vehicles to meet Euro 6 requirements. Combustion Engines. PTNSS-2015-3477.

[2] FUĆ, P., LIJEWSKI, P., ZIÓŁKOWSKI, A., SIEDLECKI, $M$. Trends in the type-approval regulations in terms of exhaust gas emissions for vehicles of category PC and LDV. Combustion Engines. PTNSS-2015-3365.

[3] MERKISZ, J., PIELECHA, I. Alternatywne napędy pojazdów. Wydawnictwo Politechniki Poznańskiej. Poznań 2006.

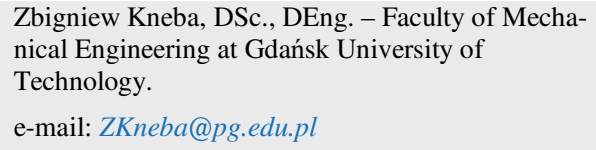

Karol Tyszkowski, MEng. - Faculty of Mechanical Engineering at Gdańsk University of Technology.

e-mail: tyk3@wp.pl
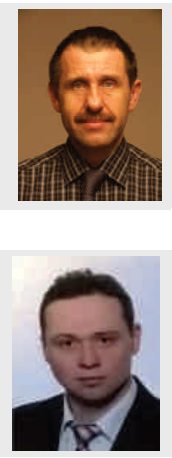

[4] MERKISZ, J., PIELECHA, J., RADZIMIRSKI, S. Pragmatyczne podstawy ochrony powietrza atmosferycznego w transporcie drogowym. Wydawnictwo Politechniki Poznańskiej. Poznań 2009.

[5] NIK: Raport Ochrona powietrza przed zanieczyszczeniami. 2014.

[6] ROMANISZYN, K. Alternatywne zasilanie samochodów benzyną oraz gazami LPG i CNG. Wydawnictwo NaukowoTechniczne. Warszawa 2007.

[7] NAYAK, V., RASHMI, G.S., CHITRAGAR, P., MOHANAN, P. Combustion characteristics and cyclic variation of a LPG fuelled MPFI four cylinder gasoline engine. Energy Procedia. 2016, 90, 470-480.

Jan Wajs, DEng. - Faculty of Mechanical Engineering at Gdańsk University of Technology.

e-mail:Jan.Wajs@pg.edu.pl

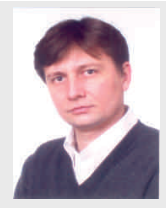

Sylwester Bieńkowski, MEng. - ELPIGAZ Sp. z o.o. Gdańsk.

e-mail:dt5@elpigaz.com

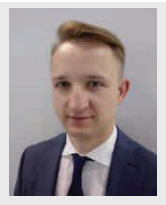

